\title{
Eileen Boris and Jennifer Klein, Caring for America: Home Health Workers in the Shadow of the Welfare State (Oxford: Oxford University Press: 2012). 320 pp. $\$ 35.00$ Paperback.
}

\section{Eileen Boris and Jennifer Klein's Caring for America: Home Wealth Workers in the} Shadow of the Welfare State arrives at a critical moment; offering a much needed, incisive, and complex history of urgent political and historical questions surrounding the gendered labour of care. In June 2014, the US Supreme Court ruled, in Harris v. Quinn, against agency-shop rules for the home health care workers in Illinois' Home Services Program, striking down the requirement that those workers who chose not to join the union would have to pay "agency fees" for union representation on the grounds that the overwhelmingly female and disproportionately women-of-colour low wage workforce was "quite different from full-fledged public employees." A subsequent January 2015, decision by US District Court Judge Richard Leon (Home Care Association of America vs. Wei) vacated a U.S. Department of Labor Rule which would have removed home health care workers from the decades-old companionship exemption to the Fair Labor Standards Act and entitled them to protection within the rubric of federal wage and hour laws. ${ }^{2}$ Both Justice Alito's definition of home care workers as "not full-fledged public employees," (in Harris v. Quinn,) and the more recent enforcement of a broad definition of the "companion" exclusion emerge from and illustrate the continuing impact of gendered and racialised histories of labour and the state. Thankfully, we have Boris and Klein's new book to help decode this moment. Caring for America incisively documents through impressive archival research, oral history, and analytical insight, the history and importance of the work and workers who have been at the center of these landmark legal disputes.

In writing about the history of home care workers, Boris and Klein are also, necessarily, writing about the history of caring labour, and, more broadly, about the feminized forms of affective labour Michael Hardt has called "labor in the bodily mode." 3 Theirs is very much a history of how particular kinds of work and workers became constructed in legislation and in courtrooms as different from and less than those which the regulatory apparatus of the New Deal was created to manage. (That difference, inextricable from workers' race and gender, in turn allowed the authors of that New Deal labour regime to exclude "domestics," including home health care workers, from its statutory protections.) The history of home care workers is not just an unstudied chapter in US labour history, it is also central to the histories of both welfare policy and disability activism in the twentieth century. Indeed, one of the most impressive qualities of Boris and Klein's writing is the effortlessness with which they navigate home 
care work's historical location at the intersection of federal labour law's racialised and gendered exclusions, the paternalistic disciplinary logic of the welfare state, the "rise of a vast medical-industrial complex," the precaritisation of labour and the "precariousness of the labor movement," the emergence of the disability rights movement, the crisis of domestic labour, and the social transformations of the working and middle classes made possible by both post-1965 immigration and by systemic racial inequality. For Boris and Klein, the history of home care is not adjunct to the history of work, industry, and the state in the twentieth century US; instead the story of those who "labor in private spaces meeting individual needs" (5) is central to the political economy of American capitalism. As Boris and Klein write in the introduction, the lives of home care workers "tell us much about the shifting relations between home and market, state and family."

Boris and Klein's analysis of home care benefits from a deeply nuanced understanding of labour, political economy, and social movement history. The struggles of workers and their unions to win collective bargaining in a legal context which often denied that what care workers did was even "work" overlapped, sometimes messily, with the history of welfare rights activism and the disability rights movement. These histories wind up being incredibly important to the history of the US labour movement, especially to large, important unions like the Service Employees International Union (SEIU) and the American Federation of State, County, and Municipal Employees (AFSCME). But, as with so much else about home care, they have been largely unchronicled and understudied. To give "home care a history" then, means, for Boris and Klein, unspooling these connections and exploring their significance, both for the present conjuncture and for the historiography of the welfare state through the perspective of care work. This rich work will prove invaluable for scholars and activists concerned with caring labour, labour feminisms, the state, and the connections between disability activism and the low-wage labour of women of colour. One opportunity for subsequent historical inquiry to engage with Boris and Klein's text lies in the ways Caring for America's understandable (and productive) focus on the state makes the history it offers nevertheless largely a national one. As Boris and Klein are certainly aware, the migrant histories of many of the women who have performed caring work trace transnational flows of labour and capital across the globe. Future research might therefore build on Boris and Klein's path-breaking contribution to the history of caring work by using transnational and comparative methodologies to offer historical accounts of home care's relationship to global histories of migration, displacement, gender, and race.

\section{NOTES}

${ }^{1}$ Harris v. Quinn, 573 USA, 2014.

2 Michelle Chen, "Judge Rules That Home Care Workers are Really Just 
'Companions',' The Nation. January 16, 2015.

3 Michael Hardt, "Affective Labor," boundary 2, 26.2 (1999): 96. Hardt quotes Dorothy Smith, The Everyday World as Problematic: A Feminist Sociology (Boston: Northeastern University Press: 1987), 78-88.

\author{
Zach Schwartz-Weinstein \\ New York University
}

\title{
Christopher M. White, A Global History of the Developing World (New York: Routledge, 2014). 275 pp. $\$ 44.95$ Paperback.
}

In this ambitious book, Christopher M. White has aimed for a short, but wideranging, history of the "developing world." Written in a style agreeable to a general readership, White is specifically concerned with speaking to undergraduate students, at times writing as though he is directly in front of them giving a lecture. Coming in at 275 pages, Global History joins a flurry of recent works seemingly aimed at capturing the first year undergraduate textbook market by offering shorter reads than the thousand page volumes common in years past.

White breaks the book into four parts: Imperialism, Nationalism, Globalization and Development. The first three parts, what he calls the "fundamentals of the modern history of the developing world"(1), are a chronological account beginning more or less with Columbus' initial encounters in the Americas in the late fifteenth century and ending around issues such as the Arab Spring protests in 2011. Undergraduate instructors will find that White's rendition of the past five hundred years touches upon many important signposts commonly found in recent world history textbooks. In each of the first three parts, chapters are organised around geographical areas: Latin America \& the Caribbean, Asia, and Africa, in other words, the "developing world" to which the book's title refers. Though he periodically gestures towards matters of religion, identity, culture and social life, for White the West's economic interests and concerns about international relations provide much of the fuel that drives the motor of his global history. "Development," the book's final part, focuses on scholars whose claims have either challenged imperialism, colonialism and capitalism in the "developing world," or have supported their expansion. White's book then ends by discussing ideas he believes offer some potential solutions to alleviate extreme poverty in the Third World.

White hopes students will use his historical narrative and the additional tools he provides (self-reflective questions, reading and film suggestions and a glossary) to challenge common assumptions they may have about the "developing world." "As college students," he writes, "you have a choice to make: do you prefer to make decisions based on preconceived notions or do you prefer to 